Article

\title{
Germination Performances of 14 Wildflowers Screened for Shaping Urban Landscapes in Mountain Areas
}

\author{
Matteo Caser*D, Sonia Demasi (D), Eric Mozzanini (D), Paola Maria Chiavazza and Valentina Scariot $(\mathbb{D}$
}

check for

updates

Citation: Caser, M.; Demasi, S.;

Mozzanini, E.; Chiavazza, P.M.; Scariot, V. Germination Performances of 14 Wildflowers Screened for Shaping Urban Landscapes in Mountain Areas. Sustainability 2022, 14, 2641. https://doi.org/10.3390/ su14052641

Academic Editor: Jasmin Mantilla-Contreras

Received: 21 January 2022 Accepted: 18 February 2022 Published: 24 February 2022

Publisher's Note: MDPI stays neutral with regard to jurisdictional claims in published maps and institutional affiliations.

Copyright: (C) 2022 by the authors. Licensee MDPI, Basel, Switzerland. This article is an open access article distributed under the terms and conditions of the Creative Commons Attribution (CC BY) license (https:/ / creativecommons.org/licenses/by/ $4.0 /)$.
Department of Agricultural, Forest and Food Sciences, University of Torino, Largo Paolo Braccini 2, 10095 Grugliasco, TO, Italy; sonia.demasi@unito.it (S.D.); eric.mozzanini@unito.it (E.M.); paolamaria.chiavazza@unito.it (P.M.C.); valentina.scariot@unito.it (V.S.)

* Correspondence: matteo.caser@unito.it; Tel.: +39-011-670-8935

\begin{abstract}
Despite the high biodiversity in the Mediterranean region, the use of wildflowers from mountain areas in urban landscaping projects is hampered by the limited information on their seed germination performances. This research evaluated germination traits of 14 native herbaceous wildflower species from northern west Italian alpine and subalpine areas. Seed germination in Petri dishes at $25^{\circ} \mathrm{C}$ was performed, applying two different photoperiod conditions (light/dark at $0 / 24 \mathrm{~h}$ or $12 / 12 \mathrm{~h}$ ). A high rate and rapid germination are key features for seed and seedling nursery production; thus, the main germination indices were evaluated: the final germination percentage, the index of germination relative to light, the time of first germination, the time to reach $50 \%$ of germinated seeds, the germination period, and the mean germination time. Overall, Bellis perennis L., Leucanthemum vulgare Lam., and Taraxacum officinale Weber, from mesophilic mountainous hilly grasslands, and Dianthus carthusianorum L. and Lavandula angustifolia Mill. from higher altitudes, turned out to be interesting. Particular attention could be paid to D. carthusianorum for germination synchrony in both growth conditions, high speed, and short germination period (8.5 and 16.2 days in the dark and in the light, respectively).
\end{abstract}

Keywords: alpine plant species; final germination percentage; germinability; germination period; native flowering species; native plants biodiversity; photoperiod; relative light germination percentage; wildflower species

\section{Introduction}

The European Environment Agency [1] states that the 'quality of life in cities depends on the existence of sufficient attractive urban green areas for people and wildlife to thrive'. Recent research indicated that the biodiversity in green areas, both within and outside cities, should be increased by using native wildflowers [2-4]. These are defined as combinations of annual or perennial herbaceous wild species suitable for sowing in low maintenance areas [5-8]. The multifunctional role of wildflowers is already well-known, as they help promote biodiversity and restore habitat, requiring low-input management [3,6,9-11].

Native plants are generally well adapted to the local pedo-climatic conditions, since they have evolved over hundreds of years to thrive in the soil and in the climate of their original area and are expected to better adapt when used in urban landscaping projects [12]. Thus, herbaceous native wildflowers can rapidly colonize poor soils, reducing erosion risk, providing natural pest control and an attractive view [13]. Recent studies reported the successful use of wildflower seed mixtures in urban areas such as urban parks, roundabouts, and green roofs, but also in buffer stripes and walls for urban vertical gardens $[2,3,10,14,15]$. Studies on habitat restoration are also available, using wildflowers for roadside revegetation and mine rehabilitation and for improving runoff quality $[10,16,17]$. However, most of the literature investigated Mediterranean species such as Calendula arvensis L., Centaurea aplolepa Moretti, Trifolium campestre Schreb., Nigella damascena L., and Silene conica L. [2-4,18,19]. Until now, only a few data have been available for alpine species [16]. 
In the alpine and subalpine zones, the large species and microhabitat diversity provide an ideal context to assess habitat-related regenerative strategies, depending on habitat provenance, main microhabitat, chorotype, and adaptation to local environmental conditions [20]. Urban and alpine areas possess stress similarities such as the presence of soils with low fertility [21-23]. Thus, alpine and subalpine wildflowers can be a possible choice to ensure plants survival in urban and stressed areas by exploiting their ability to grow in stressed habitats. For these reasons, a deeper investigation of alpine and subalpine species is required to understand their potential.

Wildflowers, however, may also have other lesser known features in order to introduce new insights into the trade of urban horticulture and propagating plants. In fact, since ancient times, wild plants have widely been used in traditional cultures for different purposes, such as food [24]. Today, the renewed interest in wild edible plants, supported by the knowledge of the healthy phytochemicals they contain, makes them definable as new functional foods, which may be used also in edible landscaping projects [25-29].

Italy has less than $3 \%$ of the European surface but supports the highest number of both animal and plant species within the European Union, as well as the highest rate of endemism [30]. Even though most native plants are well-known from a botanical point of view, little information on their germination aptitude is available [7]. The lack of specific studies on rare or endemic species is due to several limitations such as their restricted geographic distribution, the difficulty in their identification, and the absence of economic interest. The deficiency of this type of knowledge is the reason why nurseries specialized in alpine native plants propagation and the related market have not been properly developed yet. The seeds used for the reproduction of flowering and ornamental plants must possess certain requirements that meet the needs of the nursery industry. Among these, there is purity, both genetic, i.e., the guarantee of belonging to a single variety or species, and technological, i.e., not being mixed with various impurities (earth, crushed stone), and vitality. The knowledge of the environmental conditions that promote seed germination also plays a crucial role in professional lawn mixes creation. Among these, light has been seen to have varied effects on germinating seeds of different plants [31]. In some species, such as Alopecurus myosuroides Huds. [32], seeds need light to germinate (photoblastic seeds), whereas in others, such as Glaucium flavum Crantz. [33], the germination is hindered by light (non-photoblastic seeds).

This research aims to unveil the potential of herbaceous flowering plants from alpine and subalpine areas as sources of biodiversity for urban landscaping in mountain areas. For this purpose, the germination performances, under the presence or absence of light, was evaluated in 14 native wildflower species of the western Alps.

\section{Materials and Methods}

\subsection{Seed Collection}

Mature seeds of 14 native species (Figure 1) were collected in the northern west Italian alpine and subalpine areas (Table 1) during spring-summer 2017. They were cleaned from inert matter and other small debris, closed in paper bags, and kept at $4{ }^{\circ} \mathrm{C}$ without pre-dried treatment until the germination test, performed in the laboratory of the Department of Agricultural, Forest, and Food Sciences (DISAFA) of the University of Turin (Italy), during 2017 and 2018. Wild species were selected to explore all altitudinal belts in the studied area, including plain, hills, montane and alpine belts, and for their peculiar ornamental traits. 


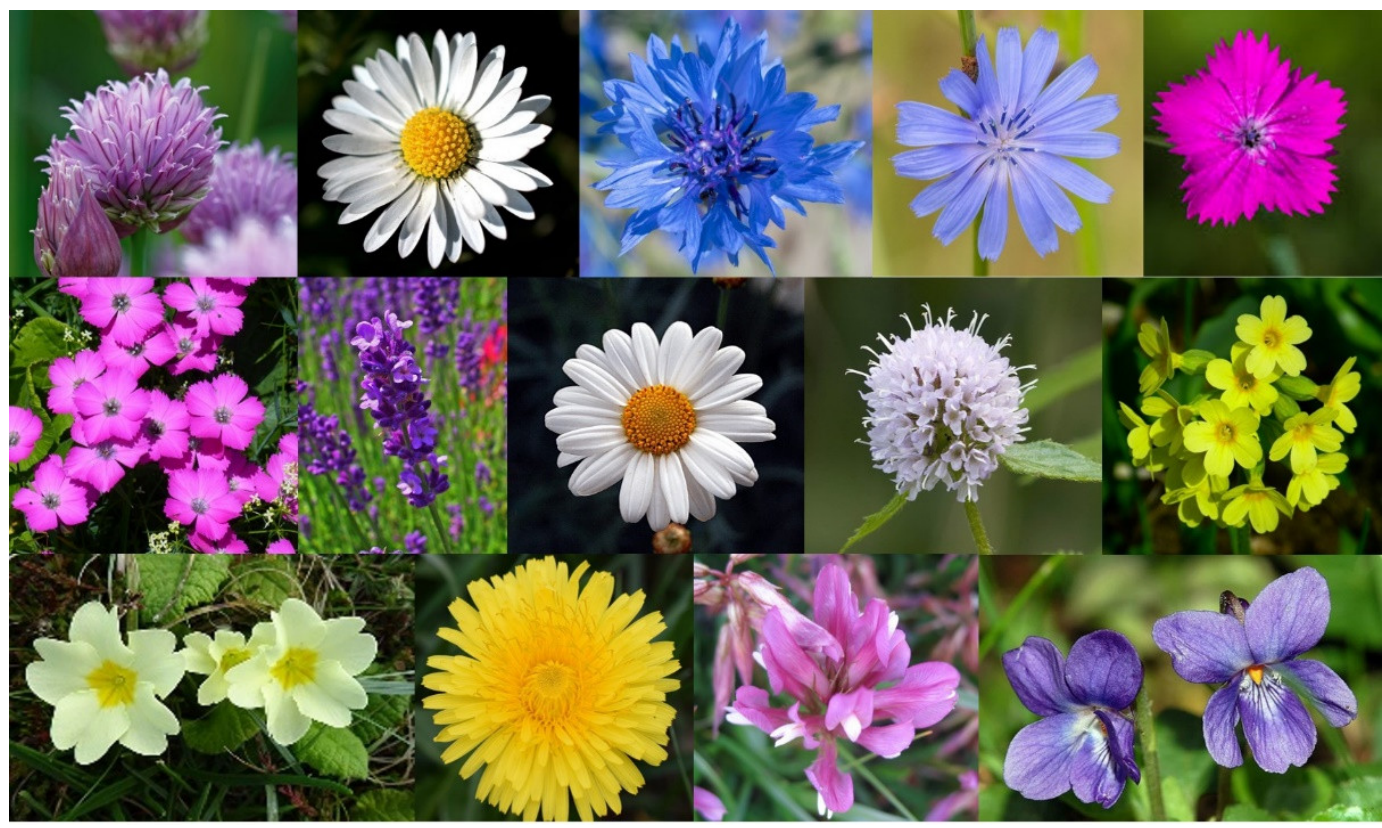

Figure 1. Detail of the flower of the fourteen native species selected for this study. From left to right, first line: Allium schoenoprasum L., Bellis perennis L., Centaurea cyanus L., Cichorium intybus L., Dianthus carthusianorum L.; second line: Dianthus pavonius Tauesch, Lavandula angustifolia Mill., Leucanthemum vulgare Lam., Mentha aquatica L., Primula veris L.; third line: Primula vulgaris Hudson, Taraxacum officinale Weber, Trifolium alpinum L., Viola odorata L.

Table 1. Taxonomy, vegetation community and geographical site references of the 14 studied alpine and sub-alpine wildflowers.

\begin{tabular}{|c|c|c|c|c|}
\hline Plant Species & Family & Site of Collection & Geographic References & Altitude (m a.s.1.) \\
\hline Allium schoenoprasum L. & Amaryllidaceae & Castelmagno $(\mathrm{CN})$ & Long 7.122 Lat 44.390 & 2293 \\
\hline Bellis perennis L. & Asteraceae & Grugliasco (TO) & Long 7.592 Lat 45.065 & 285 \\
\hline Centaurea cyanus L. & Asteraceae & Ivrea (TO) & Long 7.896 Lat 45.475 & 240 \\
\hline Cichorium intybus L. & Asteraceae & Chivasso (TO) & Long 7.843 Lat 45.192 & 189 \\
\hline Dianthus carthusianorum L. & Caryophyllaceae & Balme (TO) & Long 7.219 Lat 45.301 & 1435 \\
\hline Dianthus pavonius Tauesch & Caryophyllaceae & Castelmagno (CN) & Long 7.122 Lat 44.391 & 2393 \\
\hline Lavandula angustifolia Mill. & Lamiaceae & Grugliasco (TO) & Long 7.592 Lat 45.065 & 287 \\
\hline Leucanthemum vulgare Lam. & Asteraceae & Grugliasco (TO) & Long 7.593 Lat 45.065 & 285 \\
\hline Mentha aquatica L. & Lamiaceae & Caselette (TO) & Long 7.485 Lat 45.120 & 364 \\
\hline Primula veris $\mathrm{L}$. & Primulaceae & Cesana Torinese (TO) & Long 6.802 Lat 44.968 & 1395 \\
\hline Primula vulgaris Hudson & Primulaceae & Cesana Torinese (TO) & Long 7.379 Lat 45.145 & 774 \\
\hline Taraxacum officinale Weber & Asteraceae & Grugliasco (TO) & Long 7.593 Lat 45.064 & 285 \\
\hline Trifolium alpinum L. & Fabaceae & Castelmagno (CN) & Long 7.122 Lat 44.390 & 2385 \\
\hline Viola odorata L. & Violaceae & Grugliasco (TO) & Long 7.591 Lat 45.065 & 287 \\
\hline
\end{tabular}

\subsection{Thousand Seed Weight (TSW)}

Seeds were sorted into eight replicates of 100 seeds per each species. For each replicate, weight was recorded in grams to three decimal places by using a scale (Kern EW 220-3NM, Kern\&Sohn GmbH, Balingen, Germany), and the mean weight was determined from eight values [34]. The mean weight of 100 seeds was then used to calculate the weight of 1000 seeds (TSW). Thus, the number of seeds per gram was measured.

\subsection{Germination Test}

Based on the International Rules for Seed Testing Association (IRSTA) [34], seed germination at $25{ }^{\circ} \mathrm{C}$ was performed applying two different photoperiod conditions (light/dark at $0 / 24 \mathrm{~h}$ or $12 / 12 \mathrm{~h} ; 25-30 \mu \mathrm{mol} \mathrm{m}{ }^{-1} \mathrm{~s}^{-2}$ under cool, fluorescent white lamps). One hundred seeds were used for each species per treatment (10 repetitions by 10 seeds). Seeds were placed to germinate in $9 \mathrm{~cm}$ lidded Petri dishes containing Whatman 
No. 1 filter paper soaked in $5 \mathrm{~mL}$ of distilled water. Seeds were considered germinated when seedling structures (emergence of the radicle at the peduncle-end of the seed) were visible. Non-germinated seeds were classified as dead or vane.

Based on IRSTA [34], data were collected daily until germination values became unchanged. Six germination indices were calculated: final germination percentage (FGP), relative light germination percentage (RLGP), first germination time (FGT), halftime of germination $\left(\mathrm{T}_{50}\right)$, germination period (GPD), and mean time of germination (MTG). The formulas used to calculate the indices, explanations and references are given in Table 2.

Table 2. Germination indices and formulas used to evaluate alpine and subalpine wildflowers, with explanations and references.

\begin{tabular}{|c|c|c|c|}
\hline Germination Index & Formula & Explanation & Reference \\
\hline $\begin{array}{l}\text { Final germination percentage } \\
\text { (FGP) }\end{array}$ & $\mathrm{FGP}=100 * \mathrm{GN} / \mathrm{SN}$ & $\begin{array}{c}\mathrm{GN}=\text { total number of germinated seeds; } \mathrm{SN}=\text { total } \\
\text { number of seeds tested. }\end{array}$ & [35] \\
\hline $\begin{array}{l}\text { Relative light germination } \\
\text { percentage (RLGP) }\end{array}$ & $\mathrm{RLGP}=\mathrm{Pl} /(\mathrm{Pd}+\mathrm{Pl})$ & $\begin{array}{l}\text { RLGP is an expression of the light requirement for } \\
\text { germination. } \mathrm{Pl}=\text { percentage germination in light; } \\
\mathrm{Pd}=\text { percentage germination in shade. }\end{array}$ & [36] \\
\hline First germination time (FGT) & & $\begin{array}{l}\text { Number of days from the beginning of the } \\
\text { experiment to first germination. }\end{array}$ & [37] \\
\hline Half time of germination $\left(\mathrm{T}_{50}\right)$ & & $\begin{array}{l}\text { Number of days from the beginning of the } \\
\text { experiment to the count reached } 50 \% \text { of the } \\
\text { final germination. }\end{array}$ & [38] \\
\hline Germination period (GPD) & & $\begin{array}{l}\text { Number of days from the beginning of the } \\
\text { experiment to the maximum number of } \\
\text { seeds germinated. }\end{array}$ & [39] \\
\hline Mean germination time (MGT) & $\mathrm{MGT}=\Sigma(\mathrm{NS} * \mathrm{DAS}) / \mathrm{GN}$ & $\begin{array}{l}\text { NS = number of germinated seeds; } \\
\text { DAS = days after sowing; } \\
\text { GN = total number of germinated seeds. } \\
\text { Calculation is based on the daily count of normal } \\
\text { seedling until the final date of the germination test. }\end{array}$ & [40] \\
\hline
\end{tabular}

RLGP is expressed in values ranging from 0 (germination in dark only) to 1 (germination in light only). Therefore, species can be classified as light-dependent (1.0 > RLGP > 0.6), light-inhibited $(0<$ RLGP $<0.4)$, or intermediate $(0.4<$ RLGP $<0.6)$ [36].

Species germination performances were assessed also according to germination potential (GP), germination pattern (GPa), and germination response (GRe) as indicated by Wu et al. [31]. GP was defined as either high (FGP $>75 \%$ ), moderate (FGP 74-20\%), or low (FGP < 19\%). The GPa was defined as either synchronous, if $90 \%$ of seeds germinated within 15 days after FGT, or asynchronous in all other cases. The GRe was defined as fast (MGT $<10$ days), moderate (10 days $<$ MGT $<20$ days), or slow (MGT $>20$ days).

\subsection{Tetrazolium Assay}

The tetrazolium (TZ) assay was performed as described by Wharton [41] with slight modifications to screen for seed viability. Seeds of the species showing low final germination percentage (FGP $\leq 15 \%$ ), were first divided into slices and soaked with distilled water. After $24 \mathrm{~h}$, slices were soaked in a 1\% solution of 2,3,5-triphenyl tetrazolium chloride (SigmaAldrich S.r.l., Milan, Italy) and incubated in darkness at $35^{\circ} \mathrm{C}$ for $24 \mathrm{~h}$. TZ precipitates to red-colored 2,3,5-triphenyl formazan by the activity of dehydrogenases present in the live cells. As a result, viable seeds containing live cells stain red and nonviable or dead seeds remain unstained. Thus, the viability of seeds can be interpreted by the staining pattern and the color intensity. Data were expressed as percentage of viability. Heat-killed seeds (incubated at $100{ }^{\circ} \mathrm{C}$ for $1 \mathrm{~h}$ ) were used as a negative control.

\subsection{Statistical Analysis}

An arcsin transformation was performed on all percentage incidence data before statistical analysis in order to improve the homogeneity of the variance (Levene test; $p<0.05$ ). All the analyzed data were checked for the normality of variance by using a 
Shapiro-Wilks test $(p>0.05)$. For all the analyzed parameters not respecting the ANOVA assumptions, mean differences among species were computed using a non-parametric Kruskal-Wallis test $(p<0.05)$ by step-wise comparison. Mean differences among light treatments were computed by Mann-Whitney U-test. Statistical analyses were performed using SPSS Version 25.0 (IBM SPSS Statistic, Armonk, NY, USA). When the germination of each species was equal to or above $50 \%$ of the total number of seeds in the germination trials, the cumulative values of seed germination were plotted against time. Pearson correlation among the studied traits was conducted by using PAST 4.0 software (Natural History Museum, University of Oslo, Norway).

\section{Results and Discussion}

Germination is an irreversible process and must be timed to occur when the environment is favorable for subsequent seedling establishment [20]. Germination timing is controlled both by environmental and morphological cues such as seed weight. In the present study, species' weight differed greatly among species (Table 3). The magnitude of seed weight and number of seeds per gram ranged from $0.023 \mathrm{~g}$ and 43,478 seeds for L. vulgare to $5.710 \mathrm{~g}$ and 175 seeds for T. alpinum, with a mean of $1.198 \mathrm{~g}$ per 1000 seeds.

Table 3. Thousand seed weight (TSW) and number of seeds per gram of the studied species. Mean data of TSW are presented \pm standard deviation.

\begin{tabular}{|c|c|c|}
\hline Plant Species & TSW (g) & Seeds $\mathrm{g}^{-1}(\mathrm{n})$. \\
\hline Allium schoenoprasum & $0.968 \pm 0.011$ & 1033 \\
\hline Bellis perennis & $0.615 \pm 0.030$ & 1626 \\
\hline Centaurea cyanus & $3.440 \pm 0.030$ & 290 \\
\hline Cichorium intybus & $0.117 \pm 0.001$ & 8547 \\
\hline Dianthus carthusianorum & $0.086 \pm 0.001$ & 11,628 \\
\hline Dianthus pavonius & $0.534 \pm 0.042$ & 1873 \\
\hline Lavandula angustifolia & $0.096 \pm 0.001$ & 10,417 \\
\hline Leucanthemum vulgare & $0.023 \pm 0.001$ & 43,478 \\
\hline Mentha aquatica & $0.122 \pm 0.001$ & 8197 \\
\hline Primula veris & $0.734 \pm 0.023$ & 1362 \\
\hline Primula vulgaris & $0.966 \pm 0.018$ & 1035 \\
\hline Taraxacum officinale & $0.061 \pm 0.001$ & 16,393 \\
\hline Trifolium alpinum & $5.710 \pm 0.202$ & 175 \\
\hline Viola odorata & $3.308 \pm 0.078$ & 302 \\
\hline
\end{tabular}

Several authors highlighted the role of light availability in seed germination performances of wild species [4,42-44]. In the present study, significant differences for all the studied parameters related to seed germination were observed in both light conditions. In C. cyanus, P. veris, P. vulgaris, and V. odorata, no seeds germinated in both tested photoperiods (Table 4). These species were therefore not considered in subsequent statistical analyses.

Among the other species, in the darkness condition, FGP ranged from $0 \%$ for M. aquatica and A. schoenoprasum to $90 \%$ for L. vulgare and D. carthusianorum, while, under $12 \mathrm{~h}$ of light, between $1 \%$ for M. aquatica to $96 \%$ in L. vulgare. Within species, significant effects of light conditions were observed only for A. schoenoprasum, T. officinale, and L. angustifolia seeds, which performed better under $12 \mathrm{~h}$ of light. With respect to the germination potential (GP) of these species (Table 4), only A. schoenoprasum showed different behavior on the basis of light availability, with low germination potential in darkness and moderate under $12 \mathrm{~h}$ of light. Overall, two species have high potential (L. vulgare and D. carthusianorum), four moderate (B. perennis, C. intybus, T. officinale, and L. angustifolia), and the others low. FGP is the most important characteristic of the seed to consider in order to adopt the most effective germination protocol. Seed germination of wild species can be naturally low and variable, and some seed ecological traits can determine obstacles [16,45]. Our results, with no specific pattern, are congruent with Bu et al. [46] which assumed that 
inferences about inter-species variation in seed size and their effects on germination cannot be generalized. In fact, with an increase in seed mass, germination percentage may increase, decrease, or remain the same [31]. Furthermore, in the alpine environment, the large species and microhabitats diversity have resulted in a variety of germination responses, which makes difficult to define common germination strategy [47].

Table 4. Effect of dark $(0 / 24 \mathrm{~h})$ and photoperiod of $12 \mathrm{~h}$ of light $(12 / 12 \mathrm{~h})$ on final germination percentage (FGP, \%) of the studied species. Germination potential (GP) was described as high (FGP $>75 \%$ ), moderate (FGP 74-20\%), or low (FGP $<19 \%$ ). Relative light germination percentage (RLGP) was calculated on the FGP and species were classified as light dependent (LD; $1.0>$ RLGP $>0.6$ ), light inhibited (LI; $0<$ RLGP $<0.4$ ), or intermediate (LInt; $0.4<$ RLGP $<0.6$ ).

\begin{tabular}{|c|c|c|c|c|c|c|}
\hline \multirow{2}{*}{ Species } & \multicolumn{2}{|c|}{ FGP (\%) } & \multirow[b]{2}{*}{$p$} & \multicolumn{2}{|c|}{ GP } & \multirow{2}{*}{$\begin{array}{c}\text { RLGP } \\
\text { (Classification) }\end{array}$} \\
\hline & $0 / 24$ & $12 / 12$ & & $0 / 24$ & $12 / 12$ & \\
\hline Allium schoenoprasum & $0 \mathrm{f}$ & $23.0 \mathrm{e}$ & $* * *$ & Low & Moderate & 1.00 (LD) \\
\hline Bellis perennis & $66.0 \mathrm{~b}$ & $70.0 \mathrm{bc}$ & ns & Moderate & Moderate & 0.51 (LInt) \\
\hline Centaurea cyanus & $0 \mathrm{f}$ & $0 \mathrm{~g}$ & ns & Low & Low & - \\
\hline Cichorium intybus & $41.0 \mathrm{c}$ & $47.0 \mathrm{~d}$ & ns & Moderate & Moderate & 0.53 (LInt) \\
\hline Dianthus carthusianorum & $90.0 \mathrm{a}$ & $87.0 \mathrm{ab}$ & ns & High & High & 0.49 (LInt) \\
\hline Dianthus pavonius & $9.0 \mathrm{e}$ & $8.0 \mathrm{f}$ & ns & Low & Low & 0.47 (LInt) \\
\hline Lavandula angustifolia & $26.3 \mathrm{~d}$ & $67.6 \mathrm{c}$ & $* * *$ & Moderate & Moderate & 0.72 (LD) \\
\hline Leucanthemum vulgare & $90.0 \mathrm{a}$ & $96.0 \mathrm{a}$ & ns & High & High & 0.52 (LInt) \\
\hline Mentha aquatica & $0 \mathrm{f}$ & $1.0 \mathrm{~g}$ & ns & Low & Low & - \\
\hline Primula veris & $0 \mathrm{f}$ & $0 \mathrm{~g}$ & ns & Low & Low & - \\
\hline Primula vulgaris & $0 \mathrm{f}$ & $0 \mathrm{~g}$ & ns & Low & Low & - \\
\hline Taraxacum officinale & $63.0 \mathrm{~b}$ & $77.0 \mathrm{bc}$ & $*$ & Moderate & Moderate & $0.55(\mathrm{LInt})$ \\
\hline Trifolium alpinum & $15.0 \mathrm{de}$ & $8.0 \mathrm{f}$ & ns & Low & Low & $0.35(\mathrm{LI})$ \\
\hline Viola odorata & $0 \mathrm{f}$ & $0 \mathrm{~g}$ & ns & Low & Low & - \\
\hline
\end{tabular}

Means followed by the same letter in a column do not differ significantly, according to the Kruskal-Wallis test $\left.{ }^{* * *}=p<0.001\right)$. Mean differences among light treatments were computed by the Mann-Whitney U-test (ns $=$ non-significant, ${ }^{*}=p<0.05,{ }^{* * *}=p<0.001$ ).

Regarding the light requirement for germination (RLGP) (Table 4), two species were light-dependent (A. schoenoprasum and L. angustifolia), one was light-inhibited (T. alpinum) and the remaining were intermediate. The mean RLGP value for the studied species was 0.57. Even if the light is indicated as an important factor for plant germination, in the present study, its positive role in the germination process of wild species was confirmed only for few species. This dependence was well-rendered in literature for very small seeds such as Crepis bursifolia L. [4,36,43]. Wu et al. [31] reported that light-dependent germination may also be related to physiological dormancy, a trait that can be considered as a germination strategy in response to habitat heterogeneity.

A TZ assay was performed to check the seed viability of species with low FGP. Results in Table 5 show high values of viability for all the tested seeds, ranging between $94 \%$ in T. alpinum and $98 \%$ in V. odorata and M. aquatica. A common alpine and non-alpine germination strategy is difficult to define; in fact, many plants may require, or not, deep physiological dormancy [48-50], different light conditions, and temperatures [51-53].

Table 5. Seed viability $(\%)$ test in tetrazolium assay.

\begin{tabular}{cc}
\hline Plant Species & Seed Viability (\%) \\
\hline Centaurea cyanus & 96 \\
Dianthus pavonius & 95 \\
Mentha aquatica & 98 \\
Primula veris & 95 \\
Primula vulgaris & 97 \\
Trifolium alpinum & 94 \\
Viola odorata & 98 \\
\hline
\end{tabular}


Thus, germination failure may be due to dormancy processes that characterize many wild species [54]. Consequently, knowing how to remove dormancy represents a pivotal factor for their cultivation. Our results confirmed dormancy processes for those species as previously detected by other authors. Centaurea cyanus showed a low FGP also in a germination trial performed at 5 and $20^{\circ} \mathrm{C}$ [55]. Similarly, V. odorata seeds already showed typical hard physical dormancy [56]. In addition, previous studies have been suggesting that the seeds of Violaceae species have a seed coat with a mucilaginous inner layer that contains inhibitors, interfering with seed germination $[57,58]$. Conversely, coldtreatment and low temperature are required for P. vulgaris to reach germination [59]. Allium sphaerocephalon reached $88 \%$ of final germination, but with the use of in vitro technologies and gibberellic pre-treatment application [60].

Significant differences among species were also observed for time to first germination (FGT) and mean time of germination (MGT) traits (Table 6).

Table 6. Effect of dark $(0 / 24 \mathrm{~h})$ and photoperiod of $12 \mathrm{~h}$ of light $(12 / 12 \mathrm{~h})$ on first germination time (FGT, days) and mean time of germination (MGT, days) of the studied species. Germination pattern $(\mathrm{GPa})$ was described as either synchronous (S) or asynchronous (A). Germination response (GRe) was described as fast (F), moderate (M), or slow (S).

\begin{tabular}{|c|c|c|c|c|c|c|c|c|c|c|}
\hline \multirow{2}{*}{ Species } & \multicolumn{2}{|c|}{ FGT (Days) } & \multirow[b]{2}{*}{$p$} & \multicolumn{2}{|c|}{ GPa } & \multicolumn{2}{|c|}{ MGT (Days) } & \multirow[b]{2}{*}{$p$} & \multicolumn{2}{|c|}{ GRe } \\
\hline & $0 / 24$ & $12 / 12$ & & $0 / 24$ & $12 / 12$ & $0 / 24$ & $12 / 12$ & & $0 / 24$ & $12 / 12$ \\
\hline Allium schoenoprasum & - & $17.8 \mathrm{a}$ & - & $S$ & S & - & $21.9 \mathrm{a}$ & - & - & $S$ \\
\hline Bellis perennis & $10.0 \mathrm{~b}$ & $4.8 \mathrm{bc}$ & $* * *$ & $\mathrm{~A}$ & A & $18.5 \mathrm{~b}$ & $11.3 \mathrm{~b}$ & $* * *$ & M & M \\
\hline Centaurea cyanus & - & - & - & - & - & - & - & - & - & - \\
\hline Cichorium intybus & $4.0 \mathrm{~d}$ & $3.8 \mathrm{~cd}$ & ns & $S$ & $S$ & $5.8 \mathrm{~d}$ & $5.7 \mathrm{c}$ & ns & $\mathrm{F}$ & $\mathrm{F}$ \\
\hline Dianthus carthusianorum & $4.0 \mathrm{~d}$ & $6.4 \mathrm{~b}$ & * & $S$ & S & $5.9 \mathrm{~d}$ & $9.2 \mathrm{~b}$ & * & $\mathrm{F}$ & $\mathrm{F}$ \\
\hline Dianthus pavonius & $9.6 \mathrm{~b}$ & $22.5 \mathrm{a}$ & * & $S$ & A & $11.7 \mathrm{c}$ & $25.7 \mathrm{a}$ & $* *$ & M & S \\
\hline Lavandula angustifolia & $28.6 \mathrm{a}$ & $16.4 \mathrm{a}$ & $* * *$ & A & A & $35.2 \mathrm{a}$ & $25.8 \mathrm{a}$ & $* * *$ & $S$ & $S$ \\
\hline Leucanthemum vulgare & $6.2 c$ & $3.0 \mathrm{~d}$ & $* * *$ & $S$ & S & $10.8 \mathrm{c}$ & $4.3 \mathrm{~d}$ & $* * *$ & M & $\mathrm{F}$ \\
\hline Mentha aquatica & - & - & - & - & - & - & - & - & - & - \\
\hline Primula veris & - & - & - & - & - & - & - & - & - & - \\
\hline Primula vulgaris & - & - & - & - & - & - & - & - & - & - \\
\hline Taraxacum officinale & $4.2 \mathrm{~d}$ & $3.0 \mathrm{~d}$ & ns & $S$ & $S$ & $11.3 \mathrm{c}$ & $9.5 \mathrm{~b}$ & ns & M & F \\
\hline Trifolium alpinum & $4.5 \mathrm{~cd}$ & $5.2 \mathrm{~cd}$ & ns & $S$ & $S$ & $6.3 \mathrm{~d}$ & $5.7 \mathrm{~cd}$ & ns & $\mathrm{F}$ & F \\
\hline Viola odorata & - & - & - & - & - & - & - & - & - & - \\
\hline$p$ & $* * *$ & $* * *$ & & & & $* * *$ & $* * *$ & & & \\
\hline
\end{tabular}

Regarding FGT, in darkness, the values ranged from 4 to circa 30 days. The fastest species to germinate were C. intybus, D. carthusianorum, T. officinale, and T. alpinum (4.0, 4.0, 4.2, and 4.5 days, respectively). Conversely, the slowest was L. angustifolia with 28.6 days. Under $12 \mathrm{~h}$ of light, data ranged from 3 to more than 22 days. Cichorium intybus, T. officinale, and T. alpinum were again the quickest to germinate with 3.8, 3.0, and 5.2 days, respectively, together with $L$. vulgare (3.0). In contrast, $A$. schoenoprasum, $D$. pavonius, and L. angustifolia were the slowest $(17.8,22.5$, and 16.4 days, respectively). Within species, significant light-dependent differences were observed. Bellis perennis, L. vulgare, and L. angustifolia germinated faster in the light and D. carthusianorum and D. pavonius in the dark. As per the GPa, only the seed germination of B. perennis and L. angustifolia was asynchronous in both light conditions (Table 6). The remaining seven species were synchronous with the exception for D. pavonius, which showed different behavior, synchronous in the dark and asynchronous in the light. Asynchronous germination strategy is commonly adopted to enhance the probability of successful survival under varying environmental conditions [61]. This is generally observed for small-seeded species that may obtain a competitive advantage in time and space [31]. However, in the present study, this happened only in few small-seeded species (i.e., B. perennis, L. angustifolia, and D. pavonius). Regarding MGT, data ranged from 5.8 and 5.7 days for C. intybus to 35.2 and 
25.8 days for L. angustifolia in the dark condition and $12 \mathrm{~h}$ of light, respectively. The dark condition induced a significant increase of MGT in B. perennis, L. angustifolia and L. vulgare and a reduction in D. carthusianorum and D. pavonius In addition, regarding GRe, we found that $L$. angustifolia resulted the only species with a slow germination response in both light conditions. In contrast, $A$. schoenoprasum and D. pavonius were slower under $12 \mathrm{~h}$ of light. In this last experimental condition, T. officinale and L. vulgare seed germination moved from moderate to fast. Hence, these germination strategies may be an adaptation to variable environments. Once there is a suitable environment, rapid germination could result in the seedlings of these species taking possession of empty space in a short time [31]. However, some factors in light chamber studies are different from natural conditions, such as moisture that is constant and optimal, filter paper that is sterile, and germination inhibitors that are probably more effectively washed out [62].

The germination time courses of the different genotypes in the different light conditions, whose FGP exceeded 50\% [3] (B. perennis, T. officinale, L. vulgare, and D. carthusianorum in dark condition and also L. angustifolia in $12 \mathrm{~h}$ of light) are illustrated in Figure 2. Generally, for these species, wider lag phases (i.e., the interval from the beginning of the experiment to the onset of germination) were observed in the dark condition (Figure 2A) than with the application of $12 \mathrm{~h}$ of light (Figure 2B), with the exception for D. carthusianorum. This happened especially for B. perennis and L. vulgare seeds. These results are in agreement with those of Letchamo and Gosselin [63] and Keller [64], in which longer light period promotes faster and uniform germination for T. officinale and L. vulgare.

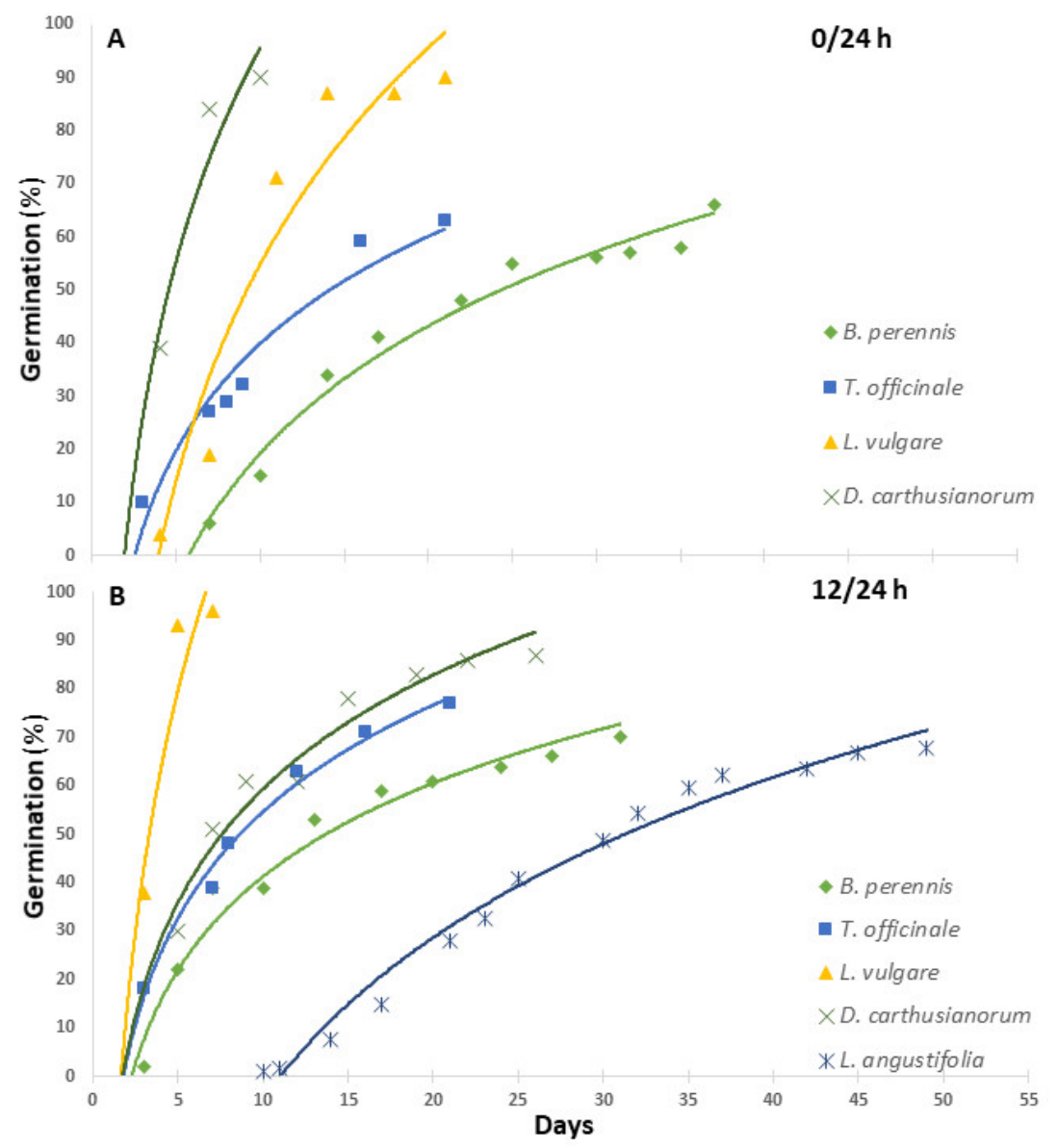

Figure 2. Germination time courses of the different species in (A) dark ( $0 / 24 \mathrm{~h})$; and in a photoperiod (B) of $12 \mathrm{~h}$ of light (12/12 h); cumulative data on seed germination of each species were represented when germination was equal to or above $50 \%$. 
Germination clearly plays a key role in the successful establishment of wildflower communities in urban landscaping. It is also important for creating a dense vegetation cover, which controls weeds, and provides the ecological benefits of a rich flowering vegetation [3]. As a consequence, some other parameters, such as rapid and uniform germination, are essential when selecting wildflower species as putative candidates for the establishment of a vegetation cover [65]. Therefore, the half time of germination and the germination period are also important features in the establishment of seed mixtures because species with a good germination percentage, a rapid onset of germination, and low $\mathrm{T}_{50}$ could be very useful and suitable for creating species-rich communities. In the present study, significant differences among species were observed in all these traits (Table 7).

Table 7. Effect of dark ( $0 / 24 \mathrm{~h})$ and photoperiod of $12 \mathrm{~h}$ of light $(12 / 12 \mathrm{~h})$ on halftime of germination $\left(\mathrm{T}_{50}\right.$, days) and germination period (GPD, days) of the studied species.

\begin{tabular}{|c|c|c|c|c|c|c|}
\hline \multirow{2}{*}{ Species } & \multicolumn{2}{|c|}{$\mathrm{T}_{50}$ (Days) } & \multicolumn{4}{|c|}{ GPD (Days) } \\
\hline & $0 / 24$ & $12 / 12$ & $p$ & $0 / 24$ & $12 / 12$ & $p$ \\
\hline Allium schoenoprasum & - & $20.8 \mathrm{a}$ & - & - & $26.6 \mathrm{~b}$ & - \\
\hline Bellis perennis & $16.8 \mathrm{~b}$ & $7.4 \mathrm{bc}$ & $* * *$ & $31.8 \mathrm{~b}$ & $23.1 \mathrm{bc}$ & * \\
\hline Centaurea cyanus & - & - & - & - & - & - \\
\hline Cichorium intybus & $4.6 \mathrm{~d}$ & $4.7 \mathrm{~d}$ & ns & 9.2 def & $9.3 \mathrm{~d}$ & ns \\
\hline Dianthus carthusianorum & $5.8 \mathrm{~d}$ & $7.8 \mathrm{bc}$ & ns & 8.5 ef & $16.2 \mathrm{c}$ & ** \\
\hline Dianthus pavonius & $9.7 \mathrm{c}$ & $24.0 \mathrm{a}$ & $* *$ & 13.8 de & $30.5 \mathrm{ab}$ & ns \\
\hline Lavandula angustifolia & $35.0 \mathrm{a}$ & $25 \mathrm{a}$ & $* * *$ & 39.8 a & $36.6 \mathrm{a}$ & * \\
\hline Leucanthemum vulgare & $11.0 \mathrm{c}$ & $5.6 \mathrm{~cd}$ & $* * *$ & $15.1 \mathrm{~d}$ & $5.6 \mathrm{~d}$ & $* * *$ \\
\hline Mentha aquatica & - & - & - & - & - & - \\
\hline Primula veris & - & - & - & - & - & - \\
\hline Primula vulgaris & - & - & - & - & - & - \\
\hline Taraxacum officinale & $11.0 \mathrm{c}$ & $9.1 \mathrm{~b}$ & ns & $17.5 \mathrm{c}$ & $15.5 \mathrm{c}$ & ns \\
\hline Trifolium alpinum & $5.0 \mathrm{~d}$ & $5.2 \mathrm{~cd}$ & ns & $6.0 \mathrm{f}$ & $6.4 \mathrm{~d}$ & * \\
\hline Viola odorata & - & - & - & - & - & - \\
\hline$p$ & $* * *$ & $* * *$ & & $* * *$ & $* * *$ & \\
\hline
\end{tabular}

Means followed by the same letter do not differ significantly, according to the Kruskal-Wallis test ( $\left.{ }^{* * *}=p<0.001\right)$ Mean differences among light treatments were computed by the Mann-Whitney U-test (ns = non-significant, $\left.{ }^{*}=p<0.05,{ }^{* *}=p<0.01,{ }^{* * *}=p<0.001\right)$.

Concerning $\mathrm{T}_{50}$, data ranged from 4.6 and 4.7 days for $C$. intybus to 35 and 25 days for L. angustifolia in dark condition and $12 \mathrm{~h}$ of light, respectively. Meanwhile, for GPD, data ranged from 6.0 days for T. alpinum to 39.8 days for L. angustifolia in dark, and between 5.6 days for $L$. vulgare to 36.6 days for L. angustifolia in $12 \mathrm{~h}$ of light. Within species, the dark condition induced a significant increase of both traits in B. perennis, L. angustifoliaand L. vulgare and reduced GPD in D. carthusianorum. It has to be considered that species that germinate in few days can hamper the emergence of other species in the mixture, exerting, in some cases, a competition for light [66]. No significant correlation (Pearson) between thousand-seed weight and the other studied traits was observed (data not shown). This is in agreement with the work of Tudela-Isanta et al. [20] on seed performances of 53 species growing in different alpine habitats.

To summarize, among the species with germinated seeds, four to nine presented moderate to higher performances in all the studied traits, namely $C$. intybus, T. officinale, L. vulgare, and D. carthusianorum. Apart for germination period, B. perennis was also of interest, especially for higher germination rate. Moreover, even if with slower aptitude to germinate, L. angustifolia showed moderate values for final germination percentage and germination potential. On the opposite, T. alpinum had very low FGP and GP but with faster germination. Allium schoenoprasum and D. pavonius presented scarce performances for all the parameters. These findings indicate that a seed mixture composed by $C$. intybus, T. officinale, L. vulgare, D. carthusianorum, B. perennis, and L. angustifolia could be effective for the composition of seed mixtures for urban areas such as urban parks, roundabouts, and green roofs but also in buffer stripes and walls for urban vertical gardens in sub-alpine urban areas. Conversely, at higher altitude, a seed mixture containing D. carthusianorum, 
T. alpinum, and L. angustifolia could be suggested. Due to the renewed interest in edible plants in landscape design [67], the use of these species can provide a unique ornamental component with additional health and aesthetic benefits.

\section{Conclusions}

Information provided in this study represent an important starting point for the implementation of innovation in the landscaping sector, supporting the production and trade of native flora seeds for new local green solutions, with particular reference to hilly and mountainous areas.

Overall, since germination rate and the onset of germination are the main points of wildflowers' use, apart from mesophilous hilly-mountain grasslands species, such as B. perennis, C. intybus, L. vulgare and T. officinale, also D. carthusianorum, and L. angustifolia, with distribution areas at higher altitude, germinated well under the tested controlled growing conditions. Thus, they could represent new validated candidates for wildflower application in anthropic environments, enhancing the biodiversity of urban vegetation in alpine and sub-alpine areas.

The obtained results of the controlled germination test have to be regarded as partial, because dormancy level may significantly vary among wild plant populations and years of seed collection. The possible recalcitrant or orthodox behavior of seeds under different storage conditions will also need to be investigated. In-depth studies on the effects of climatic conditions and substrates composition on seed germination performance in openfield conditions will have to be carried out. Moreover, evaluation of different parameters such as the mixture seeds rate, the relationship among the species, the habitus of each species, morphometric traits, and eco-physiology are therefore necessary to refine and enrich data on local alpine and sub-alpine wildflower species.

Author Contributions: Conceptualization, V.S.; methodology, M.C., S.D. and V.S.; investigation, M.C., S.D., E.M. and P.M.C.; resources, V.S.; data curation, M.C. and S.D.; writing-original draft preparation, M.C.; writing-review and editing, M.C., S.D., E.M., P.M.C. and V.S.; supervision, V.S.; funding acquisition, V.S. All authors have read and agreed to the published version of the manuscript.

Funding: This research was supported by the programs Interreg V-A Francia Italia Alcotra, project n. 1139: "ANTEA-Attività innovative per lo sviluppo della filiera transfrontaliera del fiore edule" and InterregFrancia Italia Alcotra project n. 8336: "ANTES".

Institutional Review Board Statement: Not applicable.

Informed Consent Statement: Not applicable.

Data Availability Statement: Not applicable.

Acknowledgments: Authors acknowledge Michele Lonati, Simone Ravetto Enri, Sophie Ghirardi, Niccolò Leonardi, and Walter Gaino for helping the sampling of the seeds.

Conflicts of Interest: The authors declare no conflict of interest.

\section{References}

1. European Environment Agency (EEA). The European Environment-State and Outlook 2010: Synthesis; EEA: Copenhagen, Denmark, 2010; ISBN 978-92-9213-114-2.

2. Bretzel, F.; Vannucchi, F.; Romano, D.; Malorgio, F.; Benvenuti, S.; Pezzarossa, B. Wildflowers: From conserving biodiversity to urban greening-A review. Urban For. Urban Green. 2016, 20, 428-436. [CrossRef]

3. Toscano, S.; Romano, D.; Tribulato, A.; Cavallaro, V. Assessing and modeling seed germination of Mediterranean wildflowers for low input landscape restoration. Restor. Ecol. 2018, 26, 525-536. [CrossRef]

4. Scarici, E.; Ruggeri, R.; Provenzano, M.E.; Rossini, F. Germination and performance of seven native wildflowers in the Mediterranean landscape plantings. Ital. J. Agron. 2017, 11, 163-171. [CrossRef]

5. Piotto, D.; Craven, D.; Montagnini, F.; Alice, F. Silvicultural and economic aspects of pure and mixed native tree species plantations on degraded pasturelands in humid Costa Rica. New For. 2010, 39, 369-385. [CrossRef]

6. Benvenuti, S. Wildflower green roofs for urban landscaping, ecological sustainability and biodiversity. Landsc. Urban Plan. 2014, 124, 151-161. [CrossRef] 
7. Bretzel, F.; Malorgio, F.; Vannucchi, F.; Pezzarossa, B. Wildflowers: From biodiversity conservation to landscape planning. Ital. Hort. 2013, 20, 17-31.

8. Haaland, C.; Bersier, L.-F. What can sown wildflower strips contribute to butterfly conservation? An example from a Swiss lowland agricultural landscape. J. Insect Conserv. 2010, 15, 301-309. [CrossRef]

9. Rhind, P.; Jones, R. A framework for the management of sand dune systems in Wales. J. Coast. Conserv. 2009, 13, 15-23. [CrossRef]

10. Benvenuti, S. Seed ecology of Mediterranean hind dune wildflowers. Ecol. Eng. 2016, 91, 282-293. [CrossRef]

11. Giupponi, L.; Leoni, V. VegeT: An Easy Tool to Classify and Facilitate the Management of Seminatural Grasslands and Dynamically Connected Vegetation of the Alps. Land 2020, 9, 473. [CrossRef]

12. Ruggeri, R.; Provenzano, M.; Rossini, F. Effect of mulch on initial coverage of four groundcover species for low input landscaping in a Mediterranean climate. Urban For. Urban Green. 2016, 19, 176-183. [CrossRef]

13. Bretzel, F.; Pezzarossa, B.; Benvenuti, S.; Bravi, A.; Malorgio, F. Soil influence on the performance of 26 native herbaceous plants suitable for sustainable Mediterranean landscaping. Acta Oecol. 2009, 35, 657-663. [CrossRef]

14. Bretzel, F.; Caudai, C.; Tassi, E.; Rosellini, I.; Scatena, M.; Pini, R. Culture and horticulture: Protecting soil quality in urban gardening. Sci. Total Environ. 2018, 644, 45-51. [CrossRef] [PubMed]

15. Schröder, R.; Glandorf, S.; Kiehl, K. Temporal revegetation of a demolition site-A contribution to urban restoration? J. Urban Ecol. 2018, 4, 10. [CrossRef]

16. Ladouceur, E.; Jiménez-Alfaro, B.; Marin, M.; De Vitis, M.; Abbandonato, H.; Iannetta, P.P.; Bonomi, C.; Pritchard, H.W. Native Seed Supply and the Restoration Species Pool. Conserv. Lett. 2018, 11, e12381. [CrossRef]

17. Hitchmough, J.; Woudstra, J. The ecology of exotic herbaceous perennials grown in managed, native grassy vegetation in urban landscapes. Landsc. Urban Plan. 1999, 45, 107-121. [CrossRef]

18. Benvenuti, S. Weed dynamics in the Mediterranean urban ecosystem: Ecology, biodiversity and management. Weed Res. 2004, 44, 341-354. [CrossRef]

19. Bretzel, F.; Malorgio, F.; Paoletti, L.; Pezzarossa, B. Response of sowed, flowering herbaceous communities suitable for anthropic Mediterranean areas under different mowing regimes. Landsc. Urban Plan. 2012, 107, 80-88. [CrossRef]

20. Tudela-Isanta, M.; Fernández-Pascual, E.; Wijayasinghe, M.; Orsenigo, S.; Rossi, G.; Pritchard, H.W.; Mondoni, A. Habitat-related seed germination traits in alpine habitats. Ecol. Evol. 2017, 8, 150-161. [CrossRef]

21. Groffman, P.M.; Cavender-Bares, J.; Bettez, N.D.; Grove, J.M.; Hall, S.J.; Heffernan, J.B.; Hobbie, S.E.; Larson, K.L.; Morse, J.L.; Neill, C.; et al. Ecological homogenization of urban USA. Front. Ecol. Environ. 2014, 12, 74-81. [CrossRef]

22. Grimm, N.B.; Foster, D.; Groffman, P.; Grove, J.M.; Hopkinson, C.S.; Nadelhoffer, K.J.; Pataki, D.E.; Peters, D.P. The changing landscape: Ecosystem responses to urbanization and pollution across climatic and societal gradients. Front. Ecol. Environ. 2008, 6, 264-272. [CrossRef]

23. Benvenuti, S.; Bacci, D. Initial agronomic performances of Mediterranean xerophytes in simulated dry green roofs. Urban Ecosyst. 2010, 13, 349-363. [CrossRef]

24. Petropoulos, S.; Karkanis, A.; Martins, N.; Ferreira, I. Halophytic herbs of the Mediterranean basin: An alternative approach to health. Food Chem. Toxicol. 2018, 114, 155-169. [CrossRef] [PubMed]

25. Scariot, V.; Gaino, W.; Demasi, S.; Caser, M.; Ruffoni, B. Flowers for edible gardens: Combinations of species and colours for northwestern Italy. Acta Hortic. 2018, 1215, 363-368. [CrossRef]

26. Ceccanti, C.; Landi, M.; Benvenuti, S.; Pardossi, A.; Guidi, L. Mediterranean Wild Edible Plants: Weeds or “New Functional Crops"? Molecules 2018, 23, 2299. [CrossRef] [PubMed]

27. Demasi, S.; Falla, N.M.; Caser, M.; Scariot, V. Postharvest aptitude of Begonia semperflorens and Viola cornuta edible flowers. Adv. Hortic. Sci. 2020, 34, 13-20.

28. Demasi, S.; Caser, M.; Donno, D.; Enri, S.R.; Lonati, M.; Scariot, V. Exploring wild edible flowers as a source of bioactive compounds: New perspectives in horticulture. Folia Hortic. 2021, 33, 27-48. [CrossRef]

29. Falla, N.M.; Demasi, S.; Caser, M.; Scariot, V. Preliminary Observations on Viola calcarata as a Source of Bioactive Compounds: Antioxidant Activity and Phytochemical Profile of Two Alpine Subspecies. Agronomy 2021, 11, 2241. [CrossRef]

30. Jørgensen, D. Ecological restoration in the Convention on Biological Diversity targets. Biodivers. Conserv. 2013, $22,2977-2982$. [CrossRef]

31. Wu, G.-L.; Du, G.-Z.; Shi, Z.-H. Germination strategies of 20 alpine species with varying seed mass and light availability. Aust. J. Bot. 2013, 61, 404-411. [CrossRef]

32. Colbach, N.; Chauvel, B.; Dürr, C.; Richard, G. Effect of environmental conditions on Alopecurus myosuroides germination. I. Effect of temperature and light. Weed Res. 2002, 42, 210-221. [CrossRef]

33. Thanos, C.A.; Georghiou, K.; Skarou, F. Glaucium flavum Seed Germination-An Ecophysiological Approach. Ann. Bot. 1989, 63, 121-130. [CrossRef]

34. International Rules for Seed Testing 2014; ISTA: Antalya, Turkey, 2013; ISSN 2310-3655; Available online: http:/ / www.seedtest.org/ seedhealthmethods (accessed on 19 January 2021).

35. Wang, J.H.; Baskin, C.C.; Cui, X.L.; Du, G.Z. Effect of phylogeny, life history and habitat correlates on seed germination of 69 arid and semi-arid zone species from northwest China. Evol. Ecol. 2008, 23, 827-846. [CrossRef]

36. Milberg, P.; Andersson, L.; Thompson, K. Large-seeded species are less dependent on light for germination than small-seeded ones. Seed Sci. Res. 2000, 10, 99-104. [CrossRef] 
37. Bu, H.; Du, G.; Chen, X.; Xu, X.; Liu, K.; Wen, S. Community-wide germination strategies in an alpine meadow on the eastern Qinghai-Tibet plateau: Phylogenetic and life-history correlates. Plant Ecol. 2007, 195, 87-98. [CrossRef]

38. Caser, M.; Dente, F.; Ghione, G.G.; Mansuino, A.; Giovannini, A.; Scariot, V. Shorteninng of selection time of Rosa hybrida by in vitro culture of isolated embryos and immature seeds. Prop. Ornam. Plants 2014, 14, 139-144.

39. Kumar, B.; Verma, S.K.; Singh, H. Effect of temperature on seed germination parameters in Kalmegh (Andrographis paniculata Wall. ex Nees.). Ind. Crop. Prod. 2011, 34, 1241-1244. [CrossRef]

40. Laboriau, L.G.; Valadares, M.E.B. On the germination of seeds of Calotropis procera (Ait.) Ait. f. AGRIS 1976, $48,263-284$.

41. Wharton, M.J. The use of tetrazolium test for determining the viability of seeds of the genus Brassica. Proc. Int. Seed Test. Assoc. 1955, 20, 81-88.

42. Wu, G.-L.; Du, G.-Z. Seed mass in Kobresia-dominated communities in alpine meadows at two different elevations. Isr. J. Ecol. Evol. 2009, 55, 31-40. [CrossRef]

43. Luna, B.; Moreno, J.M. Light and nitrate effects on seed germination of Mediterranean plant species of several functional groups Plant Ecol. 2008, 203, 123-135. [CrossRef]

44. Honda, Y.; Katoh, K. Strict requirement of fluctuating temperatures as a reliable gap signal in Picris hieracioides var. japonica seed germination. Plant Ecol. 2007, 193, 147-156. [CrossRef]

45. Silvertown, J.; Fenner, M. Seeds: The Ecology of Regeneration in Plant Communities. J. Ecol. 1993, 81, 384. [CrossRef]

46. Bu, H.; Chen, X.; Xu, X.; Liu, K.; Jia, P.; Du, G. Seed mass and germination in an alpine meadow on the eastern Tsinghai-Tibet plateau. Plant Ecol. 2007, 191, 127-149. [CrossRef]

47. Hoyle, G.L.; Steadman, K.; Good, R.B.; McIntosh, E.; Galea, L.M.E.; Nicotra, A.B. Seed germination strategies: An evolutionary trajectory independent of vegetative functional traits. Front. Plant Sci. 2015, 6, 731. [CrossRef]

48. Lan, Q.; Yin, S.; He, H.; Tan, Y.; Liu, Q.; Xia, Y.; Wen, B.; Baskin, C.C.; Baskin, J.M. Seed dormancy-life form profile for 358 species from the Xishuangbanna seasonal tropical rainforest, Yunnan Province, China compared to world database. Sci. Rep. 2018, 8, 4674. [CrossRef]

49. Baskin, C.C.; Baskin, J.M. Seeds: Ecology, Biogeography, and Evolution of Dormancy and Germination, 2nd ed.; Academic Press: San Diego, CA, USA, 2014; 1600p.

50. Bosco, R.; Caser, M.; Ghione, G.G.; Mansuino, A.; Giovannini, A.; Scariot, V. Dynamics of abscisic acid and indole-3-acetic acid during the early-middle stage of seed development in Rosa hybrida. Plant Growth Regul. 2014, 75, 265-270. [CrossRef]

51. Gairola, S.; Shabana, H.A.; Mahmoud, T.; Santo, A. Seed Germination of Kickxia Acerbiana, a Rare Annual of The Arabian Desert. Seed Sci. Technol. 2019, 47, 53-58. [CrossRef]

52. Jaganathan, G.K.; Liu, B. Role of seed sowing time and microclimate on germination and seedling establishment of Dodonaea viscosa (Sapindaceae) in a seasonal dry tropical environment-An insight into restoration efforts. Botany 2015, 93, 23-29. [CrossRef]

53. Schwienbacher, E.; Navarro-Cano, J.A.; Neuner, G.; Erschbamer, B. Seed dormancy in alpine species. Flora Morphol. Distrib. Funct. Ecol. Plants 2011, 206, 845-856. [CrossRef]

54. Baskin, J.M.; Baskin, C.C. A classification system for seed dormancy. Seed Sci. Res. 2004, 14, 1-16. [CrossRef]

55. Keller, M.; Kollmann, J. Effects of seed provenance on germination of herbs for agricultural compensation sites. Agric. Ecosyst. Environ. 1999, 72, 87-99. [CrossRef]

56. Barekat, T.; Otroshy, M.; Samsam-Zadeh, B.; Sadrarhami, A.; Mokhtari, A. A novel approach for breaking seed dormancy and germination in Viola odorata (A medicinal plant). J. Novel Appl. Sci. 2013, 2, 513-516.

57. Benech, R.L.; Giallorenzi, M.; Frank, J.; Rodrigvez, V. Termination of hull-imposed dormancy in developing barley grains is correlated with changes in embryonic ABA levels and sensitivity. Seed Sci. Res. 1998, 9, 39-47. [CrossRef]

58. Mares, D.J. Quarterly reports on plant growth regulation and activities of the PGRSA 32nd Annual Conference. Plant Growth Regul. Soc. Am. 2005, 33, 78-89.

59. Valverde, T.; Silvertown, J. Spatial Variation in the Seed Ecology of a Woodland Herb (Primula vulgaris) in Relation to Light Environment. Funct. Ecol. 1995, 9, 942. [CrossRef]

60. Godefroid, S.; Van de Vyver, A.; Vanderborght, T. Germination capacity and viability of threatened species collections in seed banks. Biodivers. Conserv. 2009, 19, 1365-1383. [CrossRef]

61. Moles, A.T.; Westoby, M. Seedling survival and seed size: A synthesis of the literature. J. Ecol. 2004, 92, 372-383. [CrossRef]

62. Benvenuti, S.; Pardossi, A. Germination ecology of nutraceutical herbs for agronomic perspectives. Eur. J. Agron. 2016, 76, 118-129. [CrossRef]

63. Letchamo, W.; Gosselin, A. Light, temperature and duration of storage govern the germination and emergence of Taraxacum officinale seed. J. Hortic. Sci. 1996, 71, 373-377. [CrossRef]

64. Keller, M. The Importance of Seed Source in Programmes to Increase Species Diversity in Arable Systems. Doctoral Thesis, ETH Zürich, Zürich, Switzerland, 1999. [CrossRef]

65. Bratcher, C.B.; Dole, J.M.; Cole, J.C. Stratification Improves Seed Germination of Five Native Wildflower Species. HortScience 1993, 28, 899-901. [CrossRef]

66. Nagase, A.; Dunnett, N. Performance of geophytes on extensive green roofs in the United Kingdom. Urban For. Urban Green. 2013, 12, 509-521. [CrossRef]

67. Fetouh, M.I. Edible Landscaping in Urban Horticulture. In Urban Horticulture; Nandwani, D., Ed.; Sustainable Development and Biodiversity; Springer: Cham, Switzerland, 2018; Volume 18. [CrossRef] 